\title{
Influencing Factors and Improving Measures in Relation to Track and Field Teaching Quality
}

\author{
DAI Wan-lei \\ Physical Education Department,Panzhihua University,Panzhihua,Sichuan,China
}

\begin{abstract}
This paper tries to explore an approach to solve current track and field teaching ineffective problems, and propose relative countermeasures, in order to improve the quality of teaching in track and field and the whole PE subjects teaching in PE colleges and universities.
\end{abstract}

Keywords: PE colleges and universities; track and field teaching; teaching quality; influence

\section{Basic factors influencing and re- stricting the quality of teaching}

Many influencing factors and constraints exist in specific teaching activities of $\mathrm{PE}$ colleges and universities which cover various aspects of the teaching and learning including school, teachers, students etc. Based on specific research and analysis, this paper tries to analyze 11 initial factors influencing and constraining teaching effectiveness and quality of PE colleges and universities. (see Fig. 1). In order to get the most scientific results, in the process of analysis and research, factor analysis method is used for processing relative data.

\begin{tabular}{|c|c|c|c|}
\hline code & factor & $\begin{array}{l}\text { mean } \\
\text { score }\end{array}$ & rank \\
\hline $\mathbf{A}$ & $\begin{array}{l}\text { authorities } \\
\text { recognition } \\
\text { degree }\end{array}$ & 4.3523 & 6 \\
\hline B & $\begin{array}{l}\text { degree of sci- } \\
\text { entific man- } \\
\text { agement }\end{array}$ & 4.2353 & 8 \\
\hline C & $\begin{array}{l}\text { teaching condi- } \\
\text { tions }\end{array}$ & 4.5326 & 3 \\
\hline D & expenditure & 4.3215 & 7 \\
\hline $\mathbf{E}$ & $\begin{array}{l}\text { teachers' pro- } \\
\text { fessional ded- } \\
\text { ication }\end{array}$ & 4.6354 & 2 \\
\hline $\mathbf{F}$ & teaching ability & 4.7785 & 1 \\
\hline G & $\begin{array}{l}\text { teachers' scient } \\
\text { ific research a } \\
\text { bility }\end{array}$ & 4.2137 & 9 \\
\hline H & $\begin{array}{l}\text { the students' } \\
\text { preference }\end{array}$ & 4.5211 & 4 \\
\hline I & $\begin{array}{l}\text { students' pro- } \\
\text { fessional ba- } \\
\text { sis }\end{array}$ & 4.4322 & 5 \\
\hline $\mathbf{J}$ & $\begin{array}{l}\text { teaching mate- } \\
\text { rials }\end{array}$ & 4.1372 & 10 \\
\hline $\mathbf{K}$ & $\begin{array}{l}\text { examinations } \\
\text { proportion }\end{array}$ & 4.1000 & 11 \\
\hline
\end{tabular}

Note: 5 is full mark

Fig. 1 initial statistics and factors that influence the teaching quality of PE colleges and universities 


\begin{tabular}{|c|c|c|c|}
\hline $\begin{array}{l}\text { com- } \\
\text { mon } \\
\text { factor }\end{array}$ & $\begin{array}{l}\text { co } \\
\text { de }\end{array}$ & $\begin{array}{l}\text { influencing } \\
\text { factors }\end{array}$ & $\begin{array}{l}\text { factor } \\
\text { load- } \\
\text { ings }\end{array}$ \\
\hline \multirow{3}{*}{$\begin{array}{l}\text { Teach- } \\
\text { ers fac- } \\
\text { tor }\end{array}$} & $\mathrm{F}$ & $\begin{array}{l}\text { teaching abil- } \\
\text { ity }\end{array}$ & 0.612 \\
\hline & $\mathrm{E}$ & $\begin{array}{l}\text { teachers dedi- } \\
\text { cation }\end{array}$ & 0.593 \\
\hline & G & $\begin{array}{l}\text { teachers' sci- } \\
\text { entific re- } \\
\text { search ability }\end{array}$ & 0.578 \\
\hline \multirow{2}{*}{$\begin{array}{l}\text { Stu- } \\
\text { dents } \\
\text { factor }\end{array}$} & $\mathrm{H}$ & $\begin{array}{l}\text { students' } \\
\text { preference }\end{array}$ & 0.432 \\
\hline & I & $\begin{array}{l}\text { student pro- } \\
\text { fessional basis }\end{array}$ & 0.547 \\
\hline \multirow[t]{4}{*}{$\begin{array}{l}\text { Man- } \\
\text { agemen } \\
t \text { factor }\end{array}$} & A & $\begin{array}{l}\text { authorities } \\
\text { recognition } \\
\text { degree }\end{array}$ & 0.423 \\
\hline & B & $\begin{array}{l}\text { scientific } \\
\text { management } \\
\text { degree }\end{array}$ & 0.473 \\
\hline & D & $\begin{array}{l}\text { teaching con- } \\
\text { ditions }\end{array}$ & 0.571 \\
\hline & C & expenditure & 0.489 \\
\hline \multirow{2}{*}{$\begin{array}{l}\text { Non- } \\
\text { subjec- } \\
\text { tive fac- } \\
\text { tors }\end{array}$} & $\mathrm{J}$ & $\begin{array}{l}\text { teaching ma- } \\
\text { terials }\end{array}$ & 0.449 \\
\hline & K & $\begin{array}{l}\text { examination } \\
\text { proportion }\end{array}$ & 0.462 \\
\hline
\end{tabular}

Fig. 2 factors influencing PE colleges and universities teaching quality factors classification and factor loadings

(1) The teachers factor. The teachers factor is composed of three aspects: teaching ability, teachers' professional and scientific research ability. In track and field teaching of PE colleges and universities, teachers play a vital role. In track and field teaching activities, teachers' positive attitude towards teaching, the ability to carry out teaching activities creatively and accurate insight into the problems of the students in learning and effective guidance in further teaching will directly influence the effectiveness and quality of teaching ${ }^{[2]}$. In the relative survey, more or less, students complain of teachers attitudes and behavior towards teaching.
An excellent teacher of PE college and university must demonstrate the good qualities in the specific teaching activities. These qualities include relevant teaching theory, innovative teaching methods and means, mastery of students' psychology and status ${ }^{[2]}$. However, in the above aspects, in terms of the reality of the domestic track and field teachers still need improvement, these are important factors influencing and restricting quality improvement of track and field teaching.

(2) The students factor. The students factor mainly includes students' preference, student's professional basis. In order to stimulate students' interest in the track and field, we must deepen students' understanding of the track and field, and guide students to experience and appreciate the unique charm of the track and field, teachers should use a variety of teaching methods and means to inspire students' interest. For the students professional basis, mainly focus on development and training of students for mastery of the basic skills of the track and field. For improving student professional basis, it could start with the following two aspects: to enhance the physical quality of the students, and to make the students master technical movements and professional technic of track and field. To overcome the drawbacks of traditional examoriented education through abilityoriented teaching.

(3) Management factor. In teaching of PE colleges and universities, effective management is the foundation to improve the quality of teaching. In specific management factors, mainly include two aspects, namely authorities recognization degree, and scientific management level ${ }^{[4]}$. For the scientific management degree of the of PE colleges and universities, it is necessary to explore the management approach that is able to serve in the track and field teaching and students' effective learning. Scientific management of track 
and field teaching of PE colleges and universities includes scientific management concept, scientific management methods.

(4) non-subjective factors. In hardware investment aspect, good hardware can provide the necessary conditions for carrying out the better teaching activities, higher hardware requirements is necessary especially in PE teaching. The hardware will be great improved as long as the funds fulfilled. As for teaching materials, the traditional teaching materials used in track and field teaching is too old to keep up with the progress of modern PE teaching. Therefore, to enhance the quality of teaching of PE colleges and universities, must be in accordance with scientific attitude to select teaching materials of track and field to keep up with the times. Finally, in the proportion of test scores, the examination-oriented performance assessment should be abandoned, it should have comprehensive assessment in the exam. Such comprehensive assessment should cover content that can improve integrated capabilities such as theoretical knowledge and skills training etc.

\section{Countermeasures to Improve the Teaching Quality of Track and Field}

Practice has proved that: To anything, problem-proposing is not the purpose, the key is problem-solving. Based on this understanding, as well as the discussion above on the influencing factors, this paper propose the following countermeasures to improve track and field quality of teaching.

First, we need to strengthen efforts to track and field teaching reform, change the concept of the track and field teaching

In 2003, China reformed track and field curriculum, new standards and requirements of "the track and field and outdoor sports". It is a leaping breakthrough for China's track and field teaching career, and it has important practical significance $^{[2]}$.

Track and field curriculum reform has changed the traditional teaching models and concepts, and interpret new concepts of the track and field teaching in the new situation from the perspective of the students and teaching practical aspects ${ }^{[5]}$.

It shows that we need to strengthen the reform, change teaching concepts in accordance with the requirements of the new curriculum, only in this way, it could fundamentally change the status quo of China's track and field teaching, and promote the development of track and field teaching career.

Second, we need to improve the overall quality of the track and field teachers, enhance the capacity of the track and field teachers.

First, the teaching ability of track and field teachers needs improvement. In the actual teaching process, track and field teachers must improve teaching quality, design every aspect of the teaching based on scientific, rigorous attitude. At the same time, track and field teacher must be able to inspire the enthusiasm of the students to learn and improve learning motivation. In addition, track and field teachers must enhance their own level of technical movements, demonstrate by himself or herself to improve the quality of the training.

Secondly, we must improve the professional dedication of track and field teachers. In order to effectively improve the professional dedication of track and field teachers, the key is whether they have the awareness in this respect. Therefore, in order to improve the quality and effectiveness of the track and field teaching, the track and field teachers need to improve their professional dedication by means of continually broadening, deepening and making accurate their knowledge. 
Finally, it should establish a good relationship between teachers and students. Establishing a harmonious, healthy relationship between teachers and students is vital to the quality and level of track and field teaching. For this aspect, we should start with two aspects: first, teachers and students should inwardly take the issue seriously, strengthen mutual communication and exchanges, enhance mutual understanding and respect; second, teachers and students should make actual action to improve the issue, teachers should respect for the science and students, educate students with the scientific method, and according to the specific status of each stu$\operatorname{dent}^{[6]}$.

Third, we need to make comprehensive use of various effective means to improve the quality of track and field teaching

We must respect students as the main participants, to make students actively involve into the teaching quality improvement, teachers' exemplary role can drive the enthusiasm of students, and the enthusiasm of students, in turn, is also able to inspire teachers' teaching actively. For another example, the knowledge teachers imparted must be practical, lectures should be based on objective reality and the students' specific needs. At the same time, the assessment system of the quality of teaching needs to be strengthened, exert its orientation and incentive functions, to improve track and field teaching quality by assessment. Conclusion

In conclusion, track and field teaching in PE colleges and universities exists many problems need to improve, it is imperative to strengthen the reform in this aspect. The track and field teaching is the foundation and the main channel to improve China's track and field levels, therefore, we must take effective measures to improve the quality of track and field teaching. Only in this way, can we improve the quality of teaching, and enhance the physical quality of the students, and track and field talents continually would come forth in China, improving the development of China's track and field career would be reality.

\section{References}

[1] Jiang Yinxing, Tian Guoxiang Normal Track and Field Teaching Problems and Reform Countermeasures [J] the of Gansu Education University (Natural Science ), 2002, 16 (3): 23 24

[2] Shi Zhe, Song Aihua. Teaching Investigation and Analysis of PE Colleges and Universities in Hubei Province [J]. Hubei Sports Science, 2002, 21 (1): 106 - 107

[3] Mai Xueping, Xu Ze. Strengthen Efforts to Track and Field Teaching Reform, to Promote Physical Education [J]. Sichuan Sports Science, 2002 (1): $78-80$

[4] Gu Jiqing, Tai Chongxi. Track and Field Teaching Reform Research of PE Colleges and Universities [J]. Suzhou University (Natural Science), 2002, 18 (4): 110-115

[5] Lu Hui. Construction of New Track and Field Teaching System Suitable for Social Development Needs of the New Century [J]. Guangzhou Institute of Physical Education, 2002, 22 (2): $105-107$

[6] Dong Yaling, Zhang Zhenfeng. Teaching Status quo and Countermeasures Research of PE Colleges and Universities [J]. Jilin Normal University (Natural Science), 2003 (2): $35-36$ 